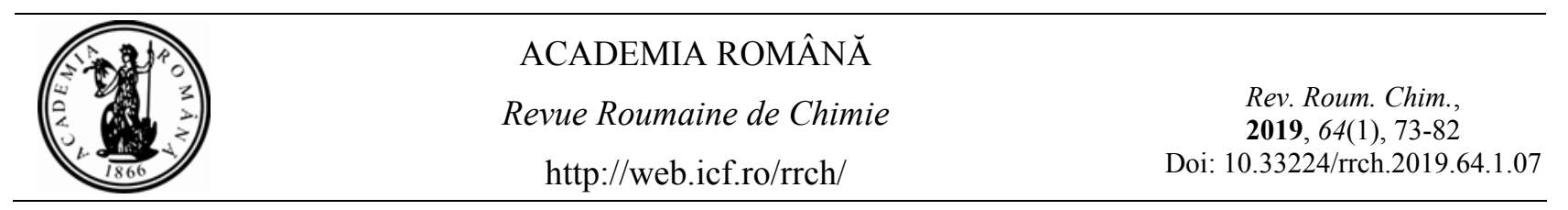

\title{
SITE-DIRECTED MUTAGENESIS AND CHARACTERIZATION OF RECOMBINANT PHOSPHOTRIESTERASE HOMOLOGY PROTEIN FROM GEOBACILLUS CALDOXYLOSILYTICUS TK4
}

\author{
Fulya OZ TUNCAY ${ }^{\mathrm{a}}$, Ahmet COLAK $^{\mathrm{a},{ }^{*}}$, Melike YILDIRIM AKATIN ${ }^{\mathrm{b}}$, Yakup KOLCUOGLU ${ }^{\mathrm{a}}$, \\ Nagihan SAGLAM ERTUNGA ${ }^{\mathrm{a}}$, Cigdem DOKUZPARMAK ${ }^{\mathrm{a}}$ \\ ${ }^{a}$ Department of Chemistry, Faculty of Science, Karadeniz Technical University, 61080 Trabzon- TURKEY \\ ${ }^{\mathrm{b}}$ Macka Vocational High School of Karadeniz Technical University, 61080 Trabzon- TURKEY
}

Received March 22,2018

\begin{abstract}
Many toxic insecticides used worldwide are organophosphates (OPs) derivatives. Phosphotriesterase (PTE) has been rewarding to protect against OP poisoning in vivo or in vitro, associated with advanced catalytic efficiency and stereoselectivity toward the hydrolysis of OPs. Phosphotriesterase homology protein (PHP) exhibits high sequence identity and similarity to PTE. In this study, site-directed mutagenesis on recombinant Geobacillus caldoxylosilyticus TK4 PHP (TK4PHP) was performed for improving the existing esterase activity, even gaining a new PTE activity. After eliminating the deficiencies in the recombinant TK4PHP gene, mutant proteins were purified and characterized biochemically. Considering all the data obtained, it was determined that the major sequence differences between PTE and TK4PHP were removed by three site-directed mutations. However the mutant TK4PHPs did not have PTE activity, it was informed that mutant esterases were more resistance to some metal ions and organic solvents and more thermal stable when it was compared with recombinant type.
\end{abstract}

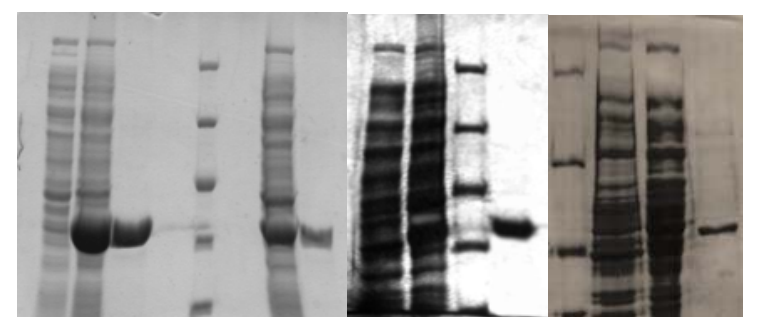

\section{INTRODUCTION}

Organophosphates (OPs) are well-known toxic compounds that inhibit a key enzyme of the central nervous system, acetylcholinesterase. OP compounds have been synthesised since the late 1940s and commonly used as insecticides and chemical warfare agents due to their hazardous properties. Late studies report that $\mathrm{OP}$ inquination in ground and drinking water, as well as grains, vegetables and fruits is at the alarming rate. ${ }^{1}$ Also, human exposure to OPs causes approximately 3 millon cases of severe poisoning and 200.000 deaths each year worldwide. ${ }^{2}$ Owing to their high acute toxicity and risk towards the environment and health, detoxifcation of OP compounds has become the subject of numerous studies. Early detection of OPs is thereby momentous not only for preserving water resources and food supplies, but also for defense against terrorist activity. ${ }^{3}$ During the past decade, enzymatic degradation of OPs has attracted an overwhelming interest, because contemporary methods of removing them, such as treatment with bleach and incineration, are impractical, expensive and cause environmental concerns. ${ }^{4}$ Hence, there is an instant need for progress of eco-friendly, efficient and reliable methods for hydrolyzation and neutralization of OPs.

The enzyme that catalyses the hydrolysis of the phosphoester bonds in OPs is termed phosphotriesterase (PTE; E.C.3.1.8.1), has been

\footnotetext{
${ }^{*}$ Correspondence to: acolak@ktu.edu.tr ; Phone: 90-462-377-2489; Fax: 90-462-325-3196
} 
detected in many bacteria as well as from squid and mammals. ${ }^{5,6}$ PTE belongs to the amidohydrolase superfamily, as such, it acquires a $\operatorname{TIM}(\beta / \alpha)$-barrel fold, a hydrophobic active site with three asunder binding pockets to correlate the substrate ester groups and two other divalent metals interact to locate the phosphorus center for catalysis. ${ }^{7,8}$ Both metals are required for full catalytic activity and are bridged by a hydroxide and a carboxylated lysine (K169) from $\beta$-strand. The native metal found in PTE is $\mathrm{Zn}^{2+}$, but substantial catalytic activity is observed with the Co-, $\mathrm{Cd}-, \mathrm{Mn}$ - or Ni-substituted forms of the enzyme. ${ }^{9}$

The closest sequence homolog known to date is phosphotriesterase homology protein (PHP), which is either a member of amidohydrolase superfamily with recondite function, showing approximately $30 \%$ sequence identity and $66 \%$ sequence similarity to PTE. Unlike PTE, PHP does not exhibit an activity of catalyzing the hydrolysis of nonspecific phosphotriesters. Studies reported a weak esterase and a weak paraoxonase activity in an Escherichia coli PHP (ECPHP) mutant. ${ }^{10}$ Whole 3D structures of both enzymes superpose quite well, and they also have a superposable binuclear $\left(\mathrm{Zn}^{2+}\right)$ metal center. Besides, analysis of an array of the primary sequence of PHP and PTE displays that the four histidine residues and the aspartate related in coordination of zinc in PTE are maintained in PHP. PHP differs from PTE in three active site loops which connect the first, seventh and eighth $\beta / \alpha$ modules. These modules, most often involved determining substrate specificity in the amidohydrolase superfamily members, are shorter in PHP. ${ }^{11,12}$ In addition, K169, zinc coordinator of PTE, substituted with E125 and shift in position in ECPHP. ${ }^{13}$

When the structural differences between diverging enzymes are minimized by laboratory evolutionary pathway, an enzyme with weak promiscuous function can exhibit a dramatically higher proficiency, even a novel activity. ${ }^{10}$ Our group identified and cloned a PHP, from the thermophile Geobacillus caldoxylosilyticus TK4 (TK4PHP). ${ }^{12}$ The enzyme has esterase activity, but not PTE activity. The residues coordinating the two catalytic metals are completely conserved (corresponding to H55, H57, H201, H230 and D301 in Pseudomonas diminuta PTE (PDPTE) (most widely studied OP-degrading enzyme) in TK4PHP (Figure 1). The sixth ligating residue corresponding to $\mathrm{K} 159$ in PTE, is conserved too, but is translocated with an $\mathrm{E}$ residue just like with ECPHP. Moreover, the 1, 7 and 8 loops are shorter (4, 14 and 9 amino acids, respectively) than
PDPTE. ${ }^{12}$ Because TK4PHP is associated with PDPTE in terms of amino acid sequence and the structure of the bimetal active site, we focused in this study on obtaining a thermostable novel OPdegrading enzyme variety by resolving the incomplete loops by site-directed mutagenesis.

The studies related to obtaining a PHP having PTE activity scarce. Formerly, several mutant forms of bacterial PTE were developed, in order to increase the promiscuous weak hydrolyzing activity. In addition, the presence of PHP was only reported for a few organisms and there are few studies regarding the mutation of PHP genes from different organisms, their expressions and characterizations. In this study, site-directed mutagenesis was performed on recombinant TK4PHP for improving the existing activity or stability. To achieve this, three loops were mutated in the recombinant TK4PHP gene. After the mutant proteins were purified, they were biochemically characterized. At the end of these studies, it was observed that $\mathrm{pH}-$ and thermal stable mutant esterases were obtained. It is well known that esterases (EC 3.1.1.1) are a class of hydrolases responsible for catalyzing the hydrolysis and formation of ester bonds. ${ }^{14}$ Since they catalyze reactions such as esterification, interesterification and trans-esterification in organic media, ${ }^{15}$ esterases, especially extracted from bacteria, have become one of the worldwide important industrial enzymes used in organic synthesis and various industrial processes (food, detergent, pharmaceutical, chemical and agricultural industries). ${ }^{16}$ Bacterial esterases have some advantages in terms of producibility in high amount, performing genetic manipulation easily and having good thermostability. ${ }^{17}$ Nowadays, even the interest in mutations of the esterases have increased greatly, the number of the mutant enzymes is still low. ${ }^{18,19}$ In the present study, pHand thermal stable esterases were obtained by conducting gene engineering methods.

\section{RESULTS AND DISCUSSION}

\section{Site-directed mutagenesis}

Across the amidohydrolase family, loops 1, 7 and 8 of the protein fold are the most diverse in structure and are thought to be responsible for differential activity between enzymes in this family. ${ }^{20}$ Gene sequence comparison revealed that loops 1, 7 and 8 differ greatly between TK4PHP and PTE. ${ }^{12}$ Therefore, the first attempt at 
improving the catalytic activity of TK4PHP was to switch these loops in TK4PHP to the corresponding loop sequences in PTE. Because loop 8 includes F306 and Y309 substrate binding units, the first mutation was applied on this loop to fulfill the 9 amino acids shortage. After that, the 14 amino acids shortening in loop 7 and 4 amino acids shortening in loop 1 was applied, respectively.
TK 4 PHPM1-M2-M3 TK4 PHPM1 -M2 TK4 PHPM1 TK 4 PHP PDPTE

TK4 PHPM1 -M2-M3 TK4 PHPM1 -M2 TK4 PHPM1 TK 4 PHP PDPTE

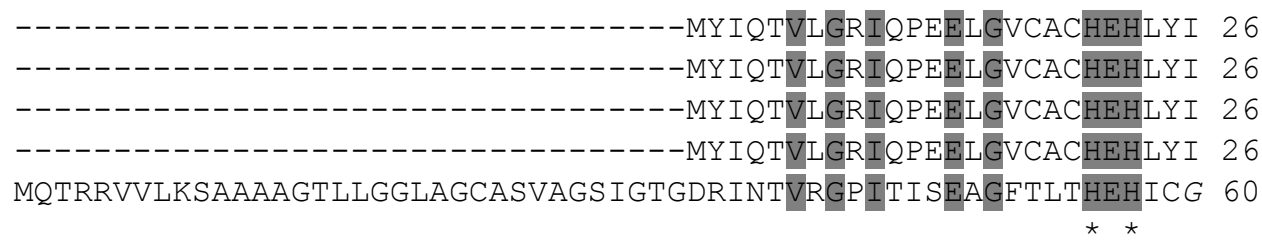

DLSRVKKNTDTCLQNRKALLDLVVEDLKVFLQYGGKAIVEMTNDGMGRNVKKLVEISKLL 86 DLSRVKKNTDTCLQN----LDLVVEDLKVFLQYGGKAIVEMTNDGMGRNVKKLVEISKLL 82 DLSRVKKNTDTCLQN----LDLVVEDLKVFLQYGGKAIVEMTNDGMGRNVKKLVEISKLL 82 DLSRVKKNTDTCLQN----LDLVVEDLKVFLQYGGKAIVEMTNDGMGRNVKKLVEISKLL 82 SSAGFLRAWPEFFGSRKALAEKAVRGLRRARAAGVRTIVDVSTFDIGRDVSLLAEVSRAA 120 Loop 1
TK4 PHPM1 -M2-M3 TK4 PHPM1 -M2 TK4 PHPM1 TK 4 PHP PDPTE

\begin{abstract}
DLHIIASTGCYKDPFI PQEKINWDRDEFAKWMIDEIENGIDGTNIKPGVIGEIGSSFNEF 146 DLHIIASTGCYKDPFIPQEKINWDRDEFAKWMIDEIENGIDGTNIKPGVIGEIGSSFNEF 142 DLHIIASTGCYKDPFI PQEKINWDRDEFAKWMIDEIENGIDGTNIKPGVIGEIGSSFNEF 142 DLHIIASTGCYKDPFIPQEKINWDRDEFAKWMIDEIENGIDGTNIKPGVIGEIGSSFNEF 142 DVHIVAATGLWFDPPLSMRLR--SVEELTQFFLREIQYGIEDTGIRAGIIK-VATTG-KA 176
\end{abstract}

TK4 PHPM1-M2-M3 TK4 PHPM1 -M2 TK 4 PHPM1 TK4 PHP PDPTE
KPVELELFYGAIEAAKTTKLPLSTHTTLG-TLALEQVELFIRENLPLHQVVIGHQDLNED 205 KPVELELFYGAIEAAKTTKLPLSTHTTLG-TLALEQVELFIRENLPLHQVVIGHQDLNED 201 KPVELELFYGAIEAAKTTKLPLSTHTTLG-TLALEQVELFIRENLPLHQVVIGHQDLNED 201 KPVELELFYGAIEAAKTTKLPLSTHTTLG-TLALEQVELFIRENLPLHQVVIGHQDLNED 201 TPFQELVLKAAARASLATGVPVTTHTAASQRDGEQQAAIFESEGLSPSRVCIGHSDDTDD 236
TK4 PHPM1-M2-M3 TK4 PHPM1 -M2 TK4 PHPM1 TK4 PHP PDPTE
DEVVLEVLSSGVYIALDTIGKENYRLEDNASASALLGIRSDMSRMKSLLYFLERGYEDQI 265 DEVVLEVLSS GVYIALDTIGKENYRLEDNASASALLGIRSDMSRMKSLLYFLERGYEDQI 261 DEVVLEVLSS GVYIALDTIGKENYR-------------SDMSRMKSLLYFLERGYEDQI 247 DEVVLEVLSSGVYIALDTIGKENYR-------------SDMSRMKSLLYFLERGYEDQI 247 LSYLTALAARGYLIGLDHIPHSA I GLEDNASASALLGIRSWQTRALLIKALIDQGYMKQI 296 Loop 7

TK4PHPM1-M2-M3 LLSSDVTRGFSSYVTNIQSHLLSRGGQGYSVVLRKFIPALREMGVLETTIEKLLVKNPQR 325 TK4PHPM1-M2 LLSSDVTRGFSSYVTNIQSHLLSRGGQGYSVVLRKFIPALREMGVLETTIEKLLVKNPQR 321

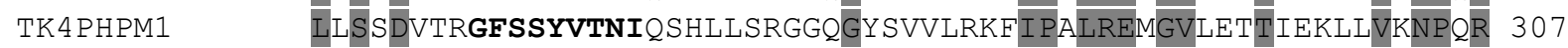
TK4PHP LLSSDVTR--------QSHLLSRGGQGYSVVLRKFIPALREMGVLETTIEKLLVKNPQR 298 PDPTE LVSNDWLFGFSSYVTNIMDVMDRVNPDGMAFIPLRVIPFLREKGVPQETLAGITVTNPAR 356 Loop 8

Fig. 1 - Sequence alignment of Pseudomonas diminuta PTE (PDPTE), Geobacillus caldoxylosilyticus TK4 PHP (TK4PHP) and the mutant variants of TK4PHP. The loops of the first, seventh and eighth $\beta / \alpha$ modules, the length of which distinguishes PTE and PHP, were stated with italic letters. The four histidine residues and the aspartate related in coordination of zinc in PTE are maintained in PHP are marked with an asterisk. 9 amino acids shortage in loop 8, 14 amino acids shortage in loop 7 and 4 amino acids shortage in loop 1 (stated with dark letters) were eliminated, respectively. 


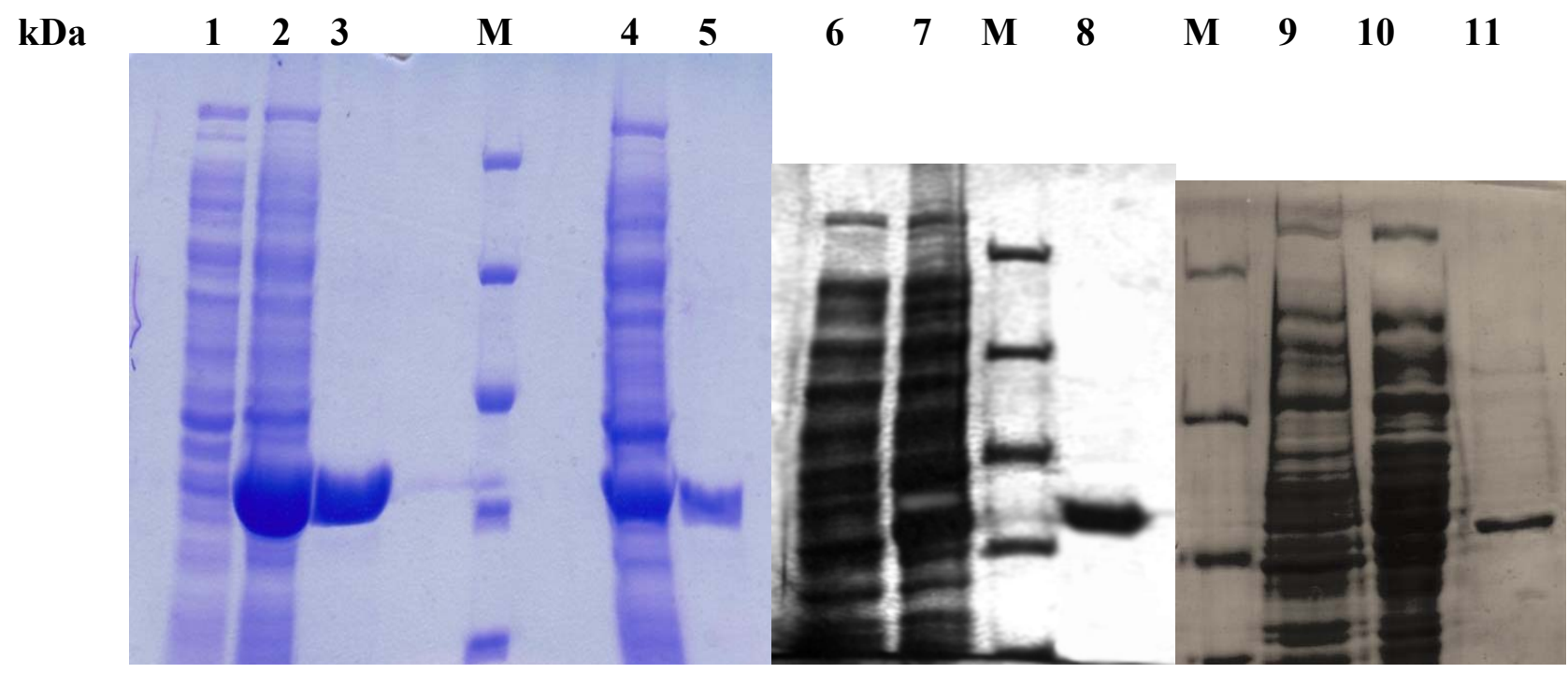

Fig. 2 - SDS polyacrylamide gel electrophoresis. Lane M, molecular weight markers; lane 1, before IPTG induction of lysate E. coli BL21(DE3)pLysS including TK4PHP; lane 2, after $3 \mathrm{~h}$ of IPTG induction of lysate $E$. coli BL21(DE3)pLysS including TK4PHP; lane 3, purified TK4PHP; lane 4, after $3 \mathrm{~h}$ of IPTG induction of lysate E. coli BL21(DE3)pLysS including TK4PHPM1; lane 5, purified TK4PHPM1; lane 6, before IPTG induction of lysate E. coli BL21(DE3)pLysS including TK4PHPM1-M2; lane 7, after 3 h of IPTG induction of lysate E. coli BL21(DE3)pLysS including TK4PHPM1-M2; lane 8, purified TK4PHPM1-M2; lane 9, before IPTG induction of lysate E. coli BL21(DE3)pLysS including TK4PHPM1-M2-M3; lane 10, after $3 \mathrm{~h}$ of IPTG induction of lysate E. coli BL21(DE3)pLysS including TK4PHPM1-M2-M3; lane 11, purified TK4PHPM1-M2-M3.

The three loops directed mutations were performed through the overlap extension PCR. The mutant TK4PHPM1 was generated using the TK4PHP as the template with the forward primer $\mathrm{M} 1 \mathrm{~F}$ and the reverse primer M1R. Then, TK4PHPM1 was used as the template to obtain the mutant TK4PHPM1-M2 with the forward primer $\mathrm{M} 2 \mathrm{~F}$ and the reverse primer M2R, so did TK4PHPM1-M2 was used as the template for the mutant TK4PHPM1-M2-M3 with the forward primer $\mathrm{M} 3 \mathrm{~F}$ and the reverse primer $\mathrm{M} 3 \mathrm{R}$. In an attempt to eleminate the template plasmids, the purified PCR products were processed with $D p n \mathrm{I}$ $(10 \mathrm{U} / \mu \mathrm{L})$ and transformed into DH5 $\alpha$ competent cells. The desired mutants were selected and sequenced. In comparison with the multiple amino acid sequences alignments from Macrogen Inc. (Seoul, Korea) and (by Clustal W Method), it was confirmed that the gaps in loop 1, 7 and 8 were fulfilled successfully (Figure 1).

\section{Protein expression and purification}

The recombinant and mutant proteins were produced under the control of T7 RNA polymerase promoter and $6 \times$ His tagged. Expression of the proteins was successfully achieved in E. coli BL21 (DE3)pLysS by the induction with $1 \mathrm{mM}$ IPTG, at $37{ }^{\circ} \mathrm{C}$ for $3 \mathrm{~h}$. Then, expressed proteins were efficiently purified to homogeneity with one-step purification procedure using nickel affinity chromatography. The molecular weight of the monomeric polypeptides determined to be approximately $36.50-38.50 \mathrm{kDa}$ by SDS polyacrylamide gel electrophoresis (Fig. 2), were also consistent with those calculated (by ProtParam) $35.57 \mathrm{kDa}$ for TK4PHPM1, $37.00 \mathrm{kDa}$ for TK4PHPM1-M2 and $37.45 \mathrm{kDa}$ for TK4PHPM1-M2-M3. These findings promoted the report of Buchbinder in which the authors reported a monomer, $32.9 \mathrm{kDa}$ ECPHP. ${ }^{13}$

\section{Determination of enzymatic activity}

To determine whether the mutant types of TK4PHP evolved for PTE activity, enzymes were evaluated for PTE efficiency with paraoxon, parathion and malathion substrates. However, no phosphotriesterase activity was detectable for the mutant enzymes. A previous study was conducted in which all loop regions in a Deinococcus radiodurans $\mathrm{PTE}$ homolog were switched to those in PTE, but no PTE activity was obtained due to the construct was found to be insoluble. ${ }^{21}$ Indeed with $\mathrm{T} 210 \mathrm{~A}$ and $\mathrm{T} 245 \mathrm{~A}$ mutations in loop 7 (located in the active site) and loop 8, an unexpectedly low level of paraoxonase activity 
appeared in the evolved ECPHP variants despite its absence in the wild-type enzyme. ${ }^{10}$

In order to examine the changes in esterase activity, mutant enzymes were studied using different p-nitrophenyl esters; acetate (C2), butirate (C4), laurate $(\mathrm{C} 12)$ and palmitate $(\mathrm{C} 16)$. While the enzymes had little or no activity for substrates with longer chain lengths, the highest activities were detected against $p$ NPA. As shown in Table 2, when the acyl chain length increased, the enzyme activities declined. The results showed a preference of the mutant enzymes for short chain fatty acids. The reported esterases from Bacillus subtilis DR8806, ${ }^{22}$ Pelagibacterium halotolerans $\mathrm{B} 2^{\mathrm{T} 23}$ and Mycobacterium tuberculosiss ${ }^{24}$ had shown substrate preference for the hydrolysis of $p$ NPA.

\section{Effect of pH and temperature on the esterase activities}

The enzyme activity assays at different $\mathrm{pHs}$ in the presence of $p \mathrm{NPA}$ as a substrate revealed that the optimum $\mathrm{pH}$ was 8.0 for TK4PHP, TK4PHPM1-M2 and TK4PHPM1-M2-M3 and 8.5 for TK4PHPM1. The optimum $\mathrm{pH}$ value of $8.0-8.5$ is similar to many other esterases. It was reported that the esterases from Geobacillus thermodenitrificans $\mathrm{T} 2$ and Bacillus cereus had maximum activity at $\mathrm{pH} 8.0$ and 8.5 , with pNPB, respectively. ${ }^{25,26}$ Moreover, the esterases from chicken with the optimum activity at $\mathrm{pH} 8.5^{27}$ and Geobacillus thermoleovorans $\mathrm{YN}$ with optimal $\mathrm{pH} 8.0$ have been reported. ${ }^{28}$

Temperature influences not only the stability of proteins but also the maximum reaction rate of enzymes by influencing the enzyme and the substrate. $^{29}$ The effect of temperature on the enzyme activities was assayed from 10 to $90{ }^{\circ} \mathrm{C}$ with an interval of $10{ }^{\circ} \mathrm{C}$. Maximum activity of TK4PHPM1 was occurred at $60{ }^{\circ} \mathrm{C}$, while TK4PHPM1-M2, TK4PHPM1-M2-M3 and the recombinant TK4PHP have an optimum at $50{ }^{\circ} \mathrm{C}$. Results also exhibited that the enzymes have proper activities between 20 and $80{ }^{\circ} \mathrm{C}$. Similar results were also reported for esterases from Picrophilus torridus, ${ }^{30}$ Bacillus cereus AGP-03, ${ }^{26}$ Pyrococcus furiosus, ${ }^{31}$ G. thermodenitrificans $\mathrm{T}^{25}$ and Thermomyces lanuginosus. ${ }^{32}$

Both $\mathrm{pH}$ and temperature optima studies easily showed that mutations performed on TK4PHP templates enhanced these properties as compared with the recombinant enzyme.

\section{Enzyme kinetics}

To compare the catalytic activities between the recombinant TK4PHP and the mutants, the kinetic values were estimated at different $p$ NPA substrate concentrations ranging from $5-800 \mu \mathrm{M}$, by Lineweaver-Burk plot (Table 3). As indicated from the results, mutant TK4PHPM1 increase its $V_{\max }$ to $14.53 \mathrm{U} / \mathrm{mg}$ proteins about a 2 -fold improvement and mutant TK4PHPM1-M2-M3 showed a lower (2.8- fold) $K_{\mathrm{m}}$ value of $0.46 \mathrm{mM}$, compared to the recombinant type. The resultant $K_{\mathrm{m}}$ values were lower than the any other previously reported esterases from Bacillus subtilis DR8806 having 4.2 $\mathrm{mM} K_{\mathrm{m}}$ value when $p$ NPA was used as substrate ${ }^{22}$ and Sulfolobus solfataricus P1 having $24.0 \mathrm{mM} K_{\mathrm{m}}$ value against $p$-nitrophenyl caprate. ${ }^{33}$

Table 2

Substrate specificities of recombinant and mutant TK4PHPs

\begin{tabular}{lcccc}
\hline \multicolumn{5}{c}{ Specific activity (U/mg protein) } \\
\hline Substrate & TK4PHP & TK4PHPM1 & TK4PHPM1-M2 & TK4PHPM1-M2-M3 \\
Paraoxon & 0 & 0 & 0 & 0 \\
Parathion & 0 & 0 & 0 & 0 \\
Malathion & 0 & 0 & 0 & 0 \\
$p$ NPA & $0.423 \pm 0.005$ & $0.616 \pm 0.005$ & $0.453 \pm 0.004$ & $0.468 \pm 0.004$ \\
$p$ NPB & $0.423 \pm 0.003$ & $0.597 \pm 0.002$ & $0.418 \pm 0.003$ & $0.427 \pm 0.002$ \\
$p$ NPL & $0.004 \pm 0.001$ & $0.005 \pm 0.001$ & $0.014 \pm 0.001$ & $0.012 \pm 0.002$ \\
$p$ NPP & 0 & 0 & $0.003 \pm 0.001$ & $0.003 \pm 0.001$ \\
\hline
\end{tabular}

\section{Table 3}

Kinetic parameters of the recombinant and mutant TK4PHPs. Enzyme kinetic assays were done using $p$-nitrophenyl acetate ( $p$ NPA) $(5-800 \mu \mathrm{M}) ; K_{\mathrm{m}}$ and $V_{\max }$ values were determined by Lineweaver-Burk plot 


\begin{tabular}{lcccc}
\hline & TK4PHP & TK4PHPM1 & TK4PHPM1-M2 & TK4PHPM1-M2-M3 \\
\hline$K_{\mathrm{m}}(\mathrm{mM})$ & $1.27 \pm 0.02$ & $1.43 \pm 0.03$ & $0.59 \pm 0.03$ & $0.46 \pm 0.02$ \\
$V_{\text {maks }}(\mathrm{U} / \mathrm{mg}$ protein $)$ & $7.59 \pm 0.03$ & $14.53 \pm 0.04$ & $3.34 \pm 0.02$ & $4.04 \pm 0.01$ \\
\hline
\end{tabular}

pH- and thermal-stability of the enzyme

To evaluate the improvement in $\mathrm{pH}$-stability, the residual activity of TK4PHP and the mutants were determined over a $\mathrm{pH}$ range from 3.0 to 9.0, after pre-incubation for 2,5 and 7 days, at $4{ }^{\circ} \mathrm{C}$. In accordance with $\mathrm{pH}$ stability studies, the mutant enzymes showed stability at a wide range of $\mathrm{pH}$. As depicted in Figure 3B, the stability of mutant TK4PHPM1 has increased by $10 \%$ in all examined $\mathrm{pHs}$ and it is indicated from Figure 3D that mutant TK4PHPM1-M2-M3 retained all of its original activity for up to 7 days. As compared to literature, mutant types of TK4PHP were $\mathrm{pH}$-stable and the enzymes may be utilized in various industrial applications. . $^{2,34,35}$

The thermostability of mutant esterases was investigated in the range of $50-90^{\circ} \mathrm{C}$, with increasing incubation time up to 7 days (Figure 4). However, no significant change in TK4PHPM1 stability was observed, the stability of TK4PHPM1-M2 and TK4PHPM1-M2-M3 increased after incubation for 7 days, compared to the recombinant enzyme. It could be suggested that the stabilities against high

(A)

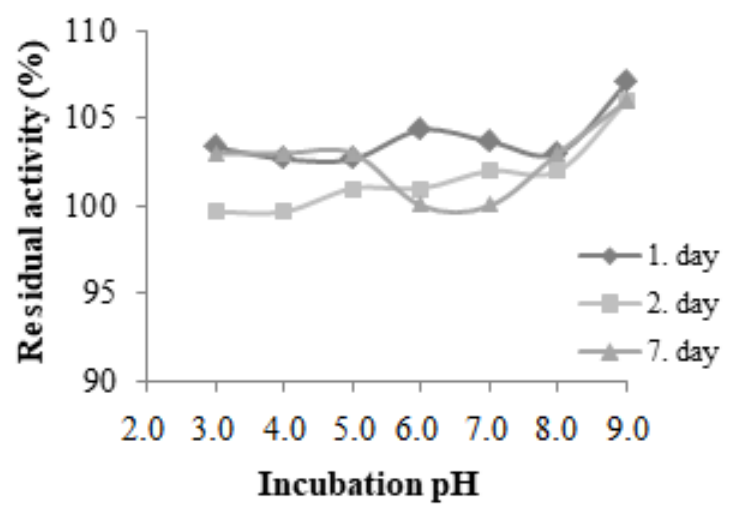

(C)

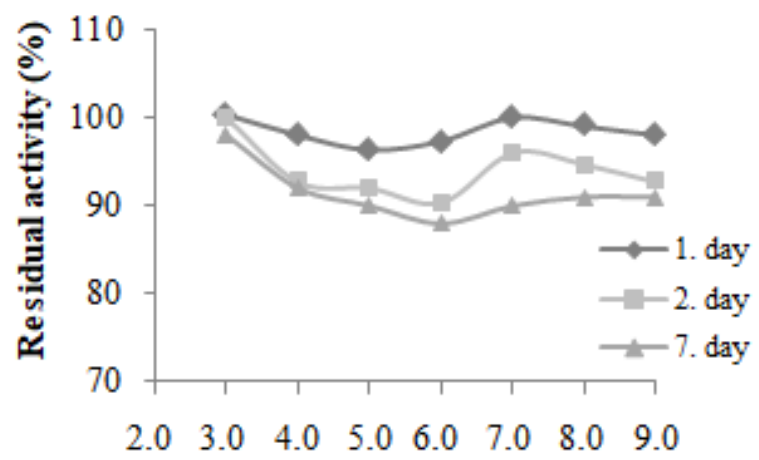

Incubation $\mathbf{p H}$ temperatures were improved by the mutations on recombinant TK4PHP. While there were several reports on thermostable esterases ${ }^{36-38}$ there were few reports considering to TK4PHP mutants.

\section{Effect of some metal ions and organic solvents}

The effect of metal ions on enzyme activity was also studied, at final concentrations of $1 \mathrm{mM}$ and 5 $\mathrm{mM}$, with $\mathrm{Na}^{+}, \mathrm{Li}^{+}, \mathrm{Mg}^{2+}, \mathrm{Mn}^{2+}, \mathrm{Zn}^{2+}, \mathrm{Ca}^{2+}, \mathrm{Co}^{2+}$ and $\mathrm{Cu}^{2+}$ ions. Our findings indicated that the activity of mutant enzymes was not affected significantly in the presence of $\mathrm{Mg}^{2+}, \mathrm{Mn}^{2+}, \mathrm{Co}^{2+}$ and $\mathrm{Ca}^{2+}$. Whereas $5 \mathrm{mM} \mathrm{Cu}{ }^{2+}$ completely inhibited the activity of recombinant TK4PHP, almost $50 \%$ of activity was found in mutant TK4PHPM1at this concentration, while the mutant TK4PHPM1-M2 was totally active. The activities of the recombinant esterase from Bacillus brevis ${ }^{39}$, thermophilic alkaline esterase from Bacillus subtilis DR8806 22, extremely thermostable Geobacillus sp. HBB-4 and Picrophilus torridus esterases were also inhibited by $\mathrm{Cu}^{2+} .30,40$

(B)

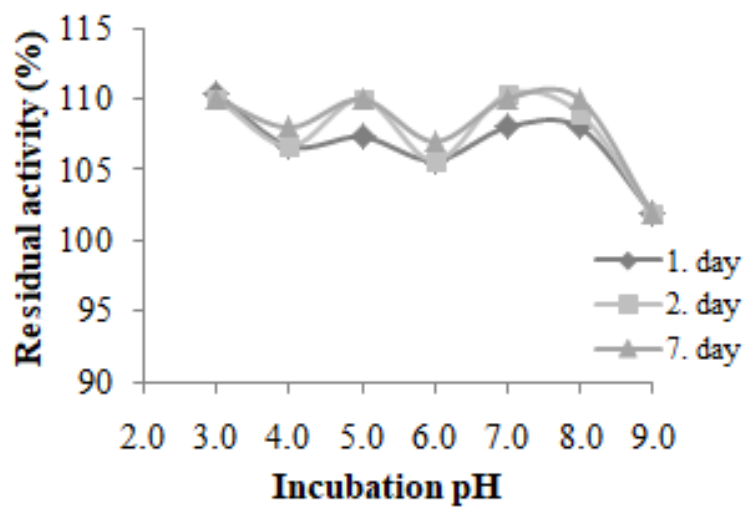

(D)

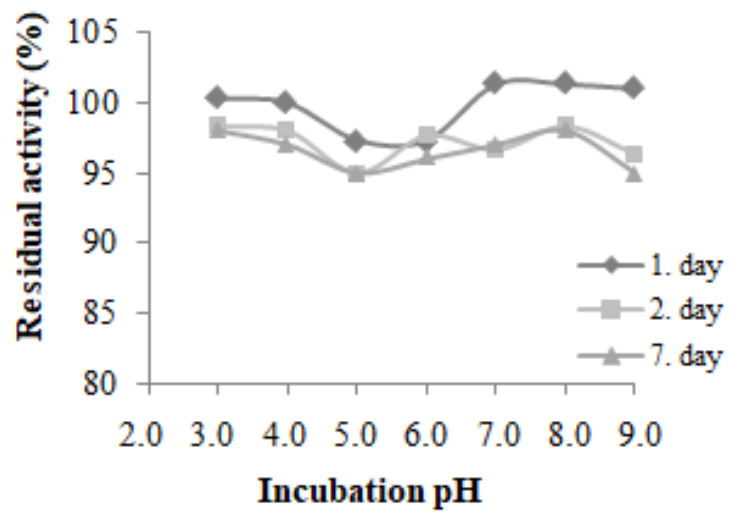


Fig. 3 - pH stability profiles of TK4PHP (A), TK4PHPM1 (B), TK4PHPM1-M2 (C), and TK4PHPM1-M2-M3 (D). Enzyme assays were done by using $p$-nitrophenyl acetate $(p \mathrm{NPA})$ as the substrate. The enzyme activities without treatment were taken as $100 \%$

(The standard deviation values were within $\pm 5 \%$ ).

\section{(A)}

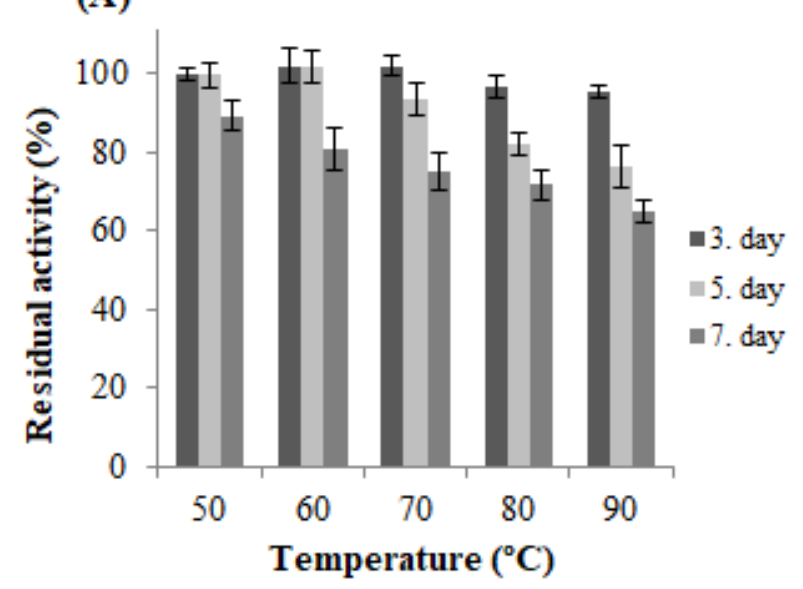

(C)

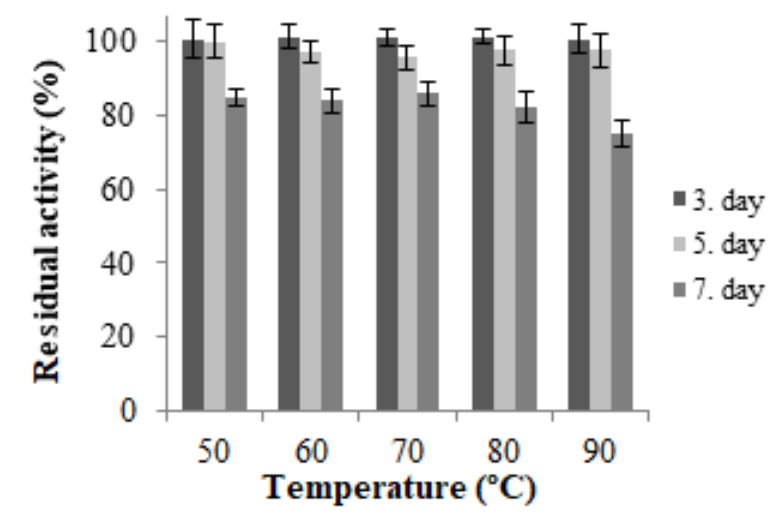

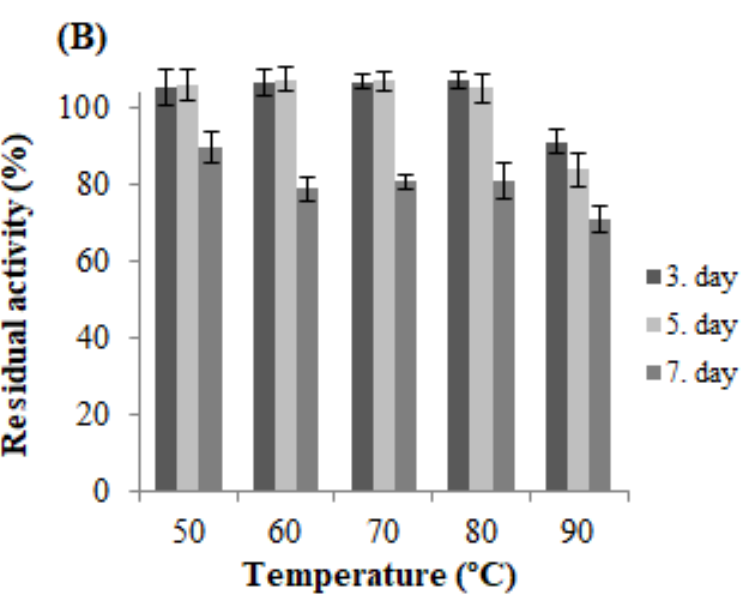

(D)

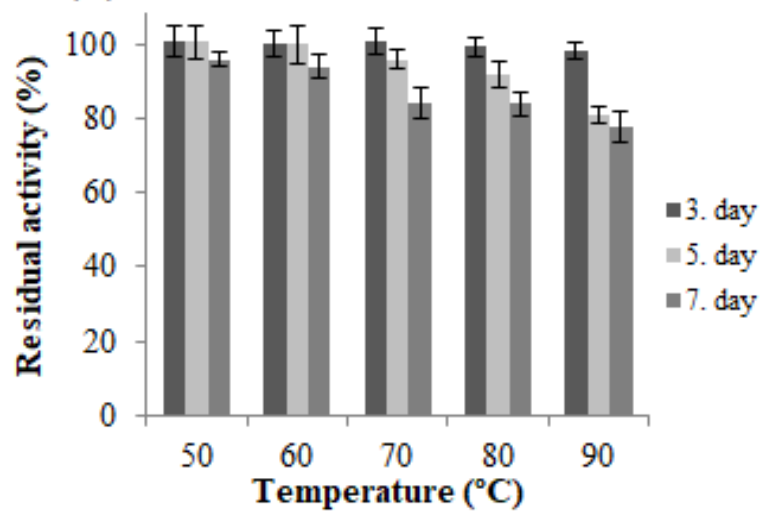

Fig. 4 - The effects of temperature on the stabilities of recombinant and mutant TK4PHPs. Enzyme assays were done by using $p$-nitrophenyl acetate $(p N P A)$ as the substrate. The thermostabilities of enzymes were determined by after incubation of purified esterases at different temperatures ranging from $50^{\circ} \mathrm{C}$ to $90{ }^{\circ} \mathrm{C}$ for 3,5 and 7 days.

Organic solvents can be advantageous in various industrial enzymatic processes as they increase the solubility of non-polar substrates and the thermal stability of enzymes, decrease the water-dependent side reactions and eliminate the microbial contamination. In this study, activities of recombinant and mutant enzymes were analyzed in the presence of acetone, acetonitrile, dimethylsulphoxide (DMSO), ethanol, isopropanol and methanol at final concentrations of $10 \%$ and $30 \%$. Although the activity of mutant TK4PHPM1 esterase was inhibited with $10 \%$ acetonitrile and acetone, an increase was observed with $30 \%$ ethanol, isopropanol, acetonitrile, acetone compared to TK4PHP. Also, TK4PHPM1M2-M3 showed higher activities toward acetonitrile and DMSO in 30\% concentration. In the presence of $10 \%$ DMSO, all mutants retained $100 \%$ relative activity as similar to a thermoalkaliphilic halotolerant esterase from Rhodococcus sp. LKE-028. ${ }^{34}$ In addition, 30\% final concentration of acetone inhibited the mutants in different ratios, likewise a thermoactive uropygial esterase from chicken. ${ }^{27}$

\section{EXPERIMENTAL}

All the chemicals in this study were of analytical grade and were purchased from Sigma (St. Louis, MO, USA), Merck A.G. (Darmstadt, Germany) or Fluka Chemie A.G. (Buchs, Switzerland). Wizard Plus SV Minipreps DNA Purification System, Wizard SV Gel and PCR Clean-Up System, MagneHis Protein Purification System were obtained from Promega (Madison, USA). Broad Range Protein Molecular Weight Markers for SDS-PAGE and $1 \mathrm{~kb}$ DNA Ladder were supplied from Fermentas (Vilnius, Lithuania). Fast PCR enzyme mix and the restriction enzyme (DpnI) were purchased from Thermo Scientific (Waltham, ABD).

The recombinant plasmid harboring TK4PHP (GenBank accession number: FJ788931) in pET-28a(+) was previously described by our group. ${ }^{12}$ The DNA sequence analyses were carried out by Macrogen Inc. (Seoul, Korea). E. coli DH5 $\alpha$ was used as the host for cloning whereas $E$. coli BL21(DE3)pLysS harbored the mutant plasmids for gene expression. Both of the strains were cultured in LB medium at $37^{\circ} \mathrm{C}$ supplemented with kanamycin $(50 \mu \mathrm{g} / \mathrm{mL})$ if required. 
The multiple amino acid sequences alignments of TK4PHP, PDPTE (known as the most active OP-degrading enzyme), Mycobacterium tuberculosis PHP (MTPHP) and ECPHP were examined ${ }^{12}$ in order to decide which mutations should be performed to give TK4PHP a novel PTE activity. So, the differences between PHP and PTE in the length of three active site loops (the loops connecting the first, seventh, and eighth $\alpha / \beta$ modules) were typically the first target in mutagenesis studies aimed at generating catalytic rate enhancements. To this end, the primers comprising the mutation locus were intended (Table 1).

The site-directed mutations were done by a one-step overlap extension PCR. TK4PHP, TK4PHPM1 and, TK4PHPM1-M2 plasmids were used as templates for PCR practices, respectively. All fragments were amplified by the same PCR run (denaturation, $94{ }^{\circ} \mathrm{C}, 1 \mathrm{~min}$; annealing, $56^{\circ} \mathrm{C}$, $1 \mathrm{~min}$; and extension, $68{ }^{\circ} \mathrm{C}, 5 \mathrm{~min} ; 30$ cycles). The PCR products were purified using the Wizard SV Gel and PCR Clean-Up System kit and used as templates for the next mutations. Mutated vectors were treated with the restriction enzyme $D p n \mathrm{I}$ for $3 \mathrm{~h}$ at $37{ }^{\circ} \mathrm{C}$ to remove the methylated template from mutant types. After transformation in $E$. coli DH5 $\alpha$ by $\mathrm{CaCl}_{2}$ method, ${ }^{41}$ cells transformed with mutant plasmids were grown in LB media with $50 \mathrm{mg} / \mathrm{mL}$ kanamycin. Plasmid isolation was performed with Wizard Plus SV Minipreps DNA Purification System. Sequence analyses of mutant plasmids were made by Macrogen Inc. (Seoul, Korea).

The mutated plasmids were transformed into E. coli BL21(DE3)pLysS and transformed cells were grown in Luria Bertani medium (LB) agar $(\mathrm{NaCl} 5 \mathrm{~g} / \mathrm{L}$, tryptone $10 \mathrm{~g} / \mathrm{L}$, yeast extract $5 \mathrm{~g} / \mathrm{L}$, agar $15 \mathrm{~g} / \mathrm{L}$ ) comprising $50 \mu \mathrm{g} / \mathrm{mL}$ kanamycin. When the $A_{600}$ reached to $0.6-0.8$, the gene expression was induced by supplementing isopropyl thio- $\beta$-d-galactoside (IPTG) at a conclusive concentration of $1 \mathrm{mM}$ and incubating for $3 \mathrm{~h}$ at $37^{\circ} \mathrm{C}$. The induced cells were harvested by centrifugation $\left(10000 \mathrm{rpm}, 4^{\circ} \mathrm{C}\right.$ and $\left.10 \mathrm{~min}\right)$, resuspended in cold $100 \mathrm{mM}$ Tris-HCl buffer ( $\mathrm{pH} 7.4$ ) containing $0.5 \mathrm{mg} / \mathrm{mL}$ lysozyme. In the wake of crashed by sonication with cooling on ice, the sonicate was fend off by centrifugation and supernatant was incubated at $70{ }^{\circ} \mathrm{C}$ for $5 \mathrm{~min}$ for prepurification. Finally, the mixture was centrifuged (10000 rpm, $4{ }^{\circ} \mathrm{C}$, and $20 \mathrm{~min}$ ) for removing the denatured proteins. As they contained $6 \times$ histidine tags at their N-termini, the mutant proteins were purified by MagneHis Protein Purification System (nickel affinity chromatography system) including paramagnetic precharged nickel particles by using a manual procedure based on the manufacturer's protocol.
Protein concentrations were determined according to the Lowry method using a calibration curve obtained with bovine serum albumin (BSA). ${ }^{42}$

SDS-PAGE (12\% acrylamide) was carried out according to Sambrook. ${ }^{43}$ Molecular weight markers were run along with samples to determine the purity of the enzymes. Protein bands were visualized by Coomassie Brilliant Blue staining R-250 staining.

PTE activity assays were performed spectrophotometrically in the presence of paraoxon, parathion and malathion substrates, with a PerkinElmer spectrophotometer, as described previously. ${ }^{44-46}$ One unit of enzymatic activity was the releasing of $1 \mu \mathrm{M}$ of $p$-nitrophenol $(p N \mathrm{~N})$ per minute.

General substrates of esterases were chosen to determine the esterolytic activity of recombinant and mutant enzymes. Enzyme activities against different $p$-nitrophenyl esters were detected spectrophotometrically by using $p$-nitrophenyl acetate ( $p$ NPA), $p$-nitrophenyl butyrate ( $p$ NPB), $p$-nitrophenyl laurate $(p N P L)$ and $p$-nitrophenyl palmitate ( $p$ NPP). $1 \mathrm{mM}$ of stock substrate solution $(10 \mathrm{mM})$ was added to a final composition of 4:95 (v/v) of ethanol/buffer (50 mM Tris-HCl, $\mathrm{pH} 8.0)$. The reaction was started by the addition of $10 \mu \mathrm{L}$ of enzyme and followed by incubation at $50{ }^{\circ} \mathrm{C}$ for $15 \mathrm{~min}$. The activity was surveyed by observing the absorbance at $405 \mathrm{~nm}$. One unit of enzymatic activity was the release of $1 \mu \mathrm{M} p \mathrm{NP}$ per minute in the above assay condition. ${ }^{47}$

Esterase activity was investigated at different $\mathrm{pH}(3.0-9.0)$ values using $50 \mathrm{mM}$ of the following buffers: Mcilvaine $(\mathrm{pH}$ 3.0-7.5) and Tris- $\mathrm{HCl}(\mathrm{pH} 7.5-9.0)$ at the optimal temperatures of the mutant enzymes. Overlapping $\mathrm{pH}$ values were used to verify that there were no buffer effects on substrate hydrolysis. Reactions were performed under standard assay protocol, using $p$ NPA as substrate. The activity was expressed as percent relative activity with respect to maximum activity, which was accepted as $100 \%{ }^{47}$

The enzyme activities were assayed at varied temperature ranging between $10{ }^{\circ} \mathrm{C}$ and $90{ }^{\circ} \mathrm{C}$ with $10{ }^{\circ} \mathrm{C}$ intervals, at optimum $\mathrm{pH}$ values by using $p \mathrm{NPA}$ as substrate, so as to detect the optimum temperature values. The activity was expressed as percent relative activity with respect to maximum activity, which was considered as $100 \%{ }^{47}$

Kinetic parameters, Michaelis-Menten constants $\left(K_{\mathrm{m}}\right)$ and the maximum reaction rates, $\left(V_{\max }\right)$ were calculated at optimal conditions, using different concentrations $(5-800 \mu \mathrm{M})$ of the $p$ NPA substrate. Each reaction at varied substrate concentration was surveyed spectrophotometrically at $405 \mathrm{~nm}$. The $K_{\mathrm{m}}$ and $V_{\max }$ values were calculated from the substrate saturation plots using Microsoft Excel software. ${ }^{48}$

Table 1

Primers for site-directed mutagenesis

\begin{tabular}{ll}
\hline Primer & Sequence (5'-3') \\
\hline M1F & gtggctttagcagctatgtgaccaacattcaatcacatttactttctcgcggegg
\end{tabular}

M1R gaatgttggtcacatagctgctaaagccacgcgttacatcgctagaaagcaag

M2F gcctggaagataacgcgagcgcgagcgcgctgctgggcattcgcagtgacatgagcc gaatgaaatcgttgc

M2R ctgcgaatgcccagcagcgegctcgegctcgegttatcttccaggcgataattctcttttcc tatcgtatctagcgegatgtatacgec 


\section{M3F atcgcaaagcgctgctggatcttgtagtagaagatttaaaag}

M3R gcagcgetttgegattttgtagacacgtatcggtatttttttaac

To examine the $\mathrm{pH}$ stabilities, the purified enzyme solutions were pre-incubated with different $\mathrm{pH}$ values using Mcilvaine (pH 3.0-7.5) and Tris- $\mathrm{HCl}(\mathrm{pH} 7.5-9.0)$ buffers, at 4 ${ }^{\circ} \mathrm{C}$, for 1,2 and 7 days. After incubation, the remaining activities of the treated samples were measured in optimal conditions, according to the standard assay. The percentage residual enzyme activities were determined by comparing with the unincubated enzyme. ${ }^{12}$

The thermal stabilities of recombinant enzymes were investigated by measuring the residual enzyme activities at varied temperatures ranging from $50{ }^{\circ} \mathrm{C}$ to $90{ }^{\circ} \mathrm{C}$ for 3,5 and 7 days. The percent residual activities were detected under standard assay conditions using $p$ NPA as substrate by comparing with unincubated enzyme. ${ }^{12}$

The effects of metal ions on enzyme activities were studied by adding various metal salts $\left(\mathrm{NaCl}, \mathrm{LiCl}, \mathrm{MgCl}_{2}\right.$, $\mathrm{MnCl}_{2}, \mathrm{ZnSO}_{4}, \mathrm{CaCl}_{2}, \mathrm{CoCl}_{2}$ and $\left.\mathrm{CuCl}_{2}\right)$ at final concentrations of $1 \mathrm{mM}$ and $5 \mathrm{mM}$ directly to the substrate mixtures, individually. After reactions were initiated by adding the purified enzymes to the substrate mixtures, they were carried out for $15 \mathrm{~min}$. The residual activities were measured by comparison with the assay mixture without any metal ion. ${ }^{12}$

To determine the effects of some organic solvents on purified esterases, methanol, ethanol, isopropanol, acetonitrile, acetone, and dimethylsulphoxide (DMSO) were added to the reaction mixtures at final concentrations of $10 \%$ and $30 \%$. Residual activities were assayed under standard conditions with $p$ NPA as substrate and calculated considering with no organic solvent inclusion. ${ }^{12}$

All experiments were performed in triplicate and the results presented are the mean of three values. The MINITAB version 16 statistical software was used for all analysis ${ }^{49}$ and the standard deviation was within $\pm 5 \%$.

\section{CONCLUSIONS}

Industrial processes often require different $\mathrm{pHs}$, as well as high temperatures and the majority of known enzymes, need to be stabilized under these conditions; therefore, there is a great interest in enzymes that are derived from thermophiles and they are stable without pretreatment. Limited thermostability and $\mathrm{pH}$ stability in operating industrial conditions are the common problems for the esterases. The mutant esterases obtained in this study on recombinant TK4PHP were more resistant to metal ions and organic solvents. Besides, the mutant enzymes exhibited significant $\mathrm{pH}$ and thermo-stability indicating that the mutant esterases described the potential to be used in harsh industrial/biotechnological processes.
Acknowledgemetns: This work was supported by The Scientific and Technological Research Council of Turkey (Project number is 109T985). The authors declare no conflicts of interest.

\section{REFERENCES}

1. R. S. Makkar, A. A. DiNovo and C. Westwater, J. Bioremed. Biodeg., 2013, 4, 1-7.

2. J. Y. Santillan, L. A. Dettorre, E. S. Lewkowicz and A. M. Iribarren, FEMS Microbiol. Lett., 2016, 363, 24.

3. G. Istamboulie, D. Fournier, J. L. Marty and T. Noguer, Talanta, 2008, 77, 1627-1631.

4. D. M. Kambiranda, S. M. Asraful-Islam, K. M. Cho, R. K. Math, Y. H. Lee, H. Kim and H. D. Yun, Pestic. Biochem. Phys., 2009, 94, 15-20.

5. L. L. Harper, C. S. McDaniel, C. E. Miller and J. R. Wild, Appl. Environ. Microbiol., 1988, 54, 2586-2589.

6. C. E. Furlong, R. J. Richter, C. Chapline and J. W. Crabb, Biochem., 1991, 30, 10133-10140.

7. N. K. Vyas, A. Nickitenko, V. K. Rastogi, S. S. Shah and F. A. Quiocho, Biochem., 2010, 49, 547-559.

8. M. Blum, F. Lohr, A. Richard, H. Ruterjans and J. C. H. Chen, J. Am. Chem. Soc., 2006, 128, 12750-12757.

9. G. A. Omburo, J. M. Kuo, L. S. Mullins and F. M. Raushel, J. Biol. Chem., 1992, 267, 13278-13283.

10. C. Roodveldt and D. S. Tawfik, Biochem., 2005, 44, 12728-12736.

11. L. Afriat, C. Roodveldt, G. Manco and D. S. Tawfik, Biochem., 2006, 45, 13677-19686.

12. M. Yildirim, A. Colak, M. Col and S. Canakci, Process Biochem., 2009, 44, 1366-1373.

13. J. L. Buchbinder, R. C. Stephenson, M. J. Dresser, J. W. Pitera, T. S. Scanlan and R. J. Fletterick, Biochem., 1998, 37, 5096-5106.

14. U.T. Bornscheuer, FEMS Microbiol. Rev., 2002, 26, 73-81.

15. T. Kawamoto, K. Sonomoto, and A. Tanaka, Biocatal. Biotransfor., 1987, 1, 137-145.

16. W. Zhang, H. Xu, Y. Wu, J. Zeng, Z. Guo, L. Wang, C. Shen, D. Qiao and Y. Cao, Int. J Biol. Macromo., 2018, 111, 1183-1193.

17. R. Gupta, N. Gupta and P. Rathi, Appl. Microbiol. Biotechnol., 2004, 64, 763-781.

18. R. Kobayashi, N. Hirano, S. Kanaya, I. Saito and M. Haruki, J. Mol. Catal. B-Enzym., 2010, 67, 155-161.

19. L. Giver, A. Gershenson, P. Freskgard and F. H. Arnold, Proc. Natl. Acad. Sci., 1998, 95, 12809-12813.

20. C. Siebert and F. Raushel, Biochem. 2005, 44, 63836391.

21. D.F. Xiang, P. Kol, A.A. Fedorov, M.M. Meier, L.V. Fedorov, T.T. Nguyen, S. Reinhard, S.C. Almo, B.K. Shoichet and F.M. Raushel, Biochem., 2009, 48, 22372247.

22. A. Asoodeh and T. Ghanbari, J. Mol. Catal. B-Enzym., 2013, 85-86, 49-55.

23. X. Wei, X. Jiang, L. Yea, S. Yuana, Z. Chena, M. Wuc and H. Yua, J. Mol. Catal. B-Enzym., 2013, 97, 207-277.

24. L. Chen, G. Dang, X. Deng, J. Cao, S. Yu, D. Wu, H. Pang and S. Liu, Protein Expres. Purif., 2014, 104, 50-56. 
25. Z. Yang, Y. Zhang, T. Shen, Y. Xie, Y. Mao and C. Ji, J. Biosci. Bioeng., 2012, 115, 133-137.

26. A.Ghati and G. Paul, Process Biochem., 2015, 50, 771-781.

27. A. Fendri, H. Louati, M. Sellami, H. Gargouri, N. Smichi, Z. Zarai, I. Aissa, N. Miled and Y. Gargouri, Int. J. Biol. Macromol., 2012, 50, 1238-1244.

28. N. A. Soliman and A. A. Gaballa, J. Biothecnol., 2013, 8, 2-10.

29. J. Dong, W. Zhao, A. A. Mohammed, G. Jingtao Sunc, X. Hua, W. Zhang, L. Han, Y. Fan, Y. Feng, Q. Shen and R. Yang, J. Mol. Catal. B-Enzym., 2015, 121, 53-63.

30. M. Hess, M. Katzer and G. Antranikian, Extremophiles, 2008, 12, 351-364.

31. R. V. Almeida, S. M. C. Alqueres, A. L. Larentis, S. C. Rössle, A. M. Cardoso, W. I. Almeida, P. M. Bisch, T. L. M. Alves and O. B. Martins, Enzyme Microb. Tech., 2006, 39, 1128-1136.

32. X. J. Li, R. C. Zheng, Z. M. Wu, X. Ding and Y. G. Zheng, Protein Express. Purif., 2014, 101, 1-7.

33. J. K. Nam, Y. J. Park and H. B. Lee, J. Mol. Catal. BEnzym., 2013, 94, 95-103.

34. L. Kumar, B. Singh, D. A. Kumar, J. Mukherjee and D. Ghosh, Process Biochem., 2012, 47, 983-991.

35. S. Zhang, G. Wu, S. Feng and Z. Liu, Enzyme Microb. Tech., 2014, 64-65, 11-16.

36. S. Torres, M. D. Baigori, S. L. Swathy, A. Pandey and G. R. Castro, Food Res. Int., 2009, 42, 454-460.
37. S. Kakugawa, S. Fushinobu, T. Wakagi, and H.Shoun, Appl. Microbiol. Biotechnol., 2007, 74, 585-591.

38. B. B. Ateşlier and K. Metin, Enzyme Microb. Tech., 2006, 38, 628-635.

39. Y. Amaki, E. E. Tulın, S. Ueda, K. Ohmiy and T. Yamane, Biosci. Biotech. Bioch., 1992, 56, 238-241.

40. K. Metin, B. B., Ateslier, G. Basbulbul and H. H. Biyik, J. Basic. Microbiol., 2006, 46, 400-409.

41. T. Maniatis, E. F. Fritsch and J. Sambrook, "Molecular cloning: a laboratory manual", Cold Spring Harbor Laboratory Press, New York, 1989.

42. O. H. Lowry, N. J. Rosebrough, A. L. Farr and R. J. Randall, J. Biol. Chem., 1951, 193, 265-275.

43. J. Sambrook and D. W. Russell, "Molecular cloning: A laboratory manual", Cold Spring Harbor Press, New York, 2001.

44. R. Gao, Y. Feng, K. Ishikawa, H. Ishida, S. Ando and Y. Kosugi, J. Mol. Catal. B-Enzym., 2003, 24, 1-8.

45. X-Y. Chu, N-F. Wu, M-J. Deng, J. Tian, B. Yao and Y-L. Fan, Protein Expr. Purif., 2006, 49, 9-14.

46. K. Lai, N. J. Stolowich and J. R. Wild, Arch. Biochem. Biophys., 1995, 318, 59-64.

47. E. Ozbek, Y. Kolcuoglu, L. Konak, A. Colak and F. Oz, Turk. J. Chem. 2014, 38, 538-46.

48. F. Öz, A. Colak, A. Özel, N. Saglam Ertunga and E. Sesli, J. Food Biochem., 2013, 37, 36-44.

49. U. Cakmak and N.Saglam Ertunga, J. Mol. Catal. BEnzym., 2017, 133, 288-298. 